\title{
Synthesis of Poly (Ether Ether) Ketone Sulfonated Membrane with Tin Dioxide Particles
}

\author{
Liz Contino Vianna de Aguiar $^{1 *}$, Florêncio Gomes de Ramos Filho ${ }^{2}$, Carla Akimi Kawaguti ${ }^{1}$, \\ Ailton de Souza Gomes ${ }^{1}$ \\ ${ }^{1}$ Universidade Federal do Rio de Janeiro, Instituto de Macromoléculas Professora Eloisa Mano, \\ Rio de Janeiro, Brazil \\ ${ }^{2}$ Centro Universitário Estadual da Zona Oeste-UEZO, Rio de Janeiro, Brazil \\ Email: "lizcontino@ima.ufrj.br
}

Received 22 December 2015; accepted 12 February 2016; published 17 February 2016

Copyright (C) 2016 by authors and Scientific Research Publishing Inc.

This work is licensed under the Creative Commons Attribution International License (CC BY).

http://creativecommons.org/licenses/by/4.0/

(c) (i) Open Access

\begin{abstract}
The development of clean energy sources is a subject in focus and boosts fuel cells for research. In this context, studies on proton conductive membranes have an important role. In the present work two groups of membranes were synthetized: one contained $\mathrm{SPEEK} / \mathrm{SnO}_{2}$ (varying the content of tin oxide from $2 \%, 4 \%$ and $6 \%$ ) and the other with SPEEK/SnO $2 / \mathrm{HPW}$. The change in the membrane structure was characterized by $\mathrm{X}$-ray diffraction, the swelling in water and ethanol solution uptake test, thermal stability using TGA, change in $T_{g}$ in DSC, the selective permeability by pervaporation test in water and the solution ethanol and proton conductivity by impedance spectroscopy. Through these analyses, it is possible to verify some effects: the tin oxide particles reduced the $T_{g}$ membranes, they also controlled the membranes swelling in water and kept it approximately $30 \%$ lower than the pure SPEEK swelling and finally, among the tin oxide quantities tested in the membranes, it was reached $67.8 \mathrm{mS} / \mathrm{cm}$ as maximum value of proton conductivity.
\end{abstract}

\section{Keywords}

Membrane, SPEEK, Tin Oxide, HPW, Proton Conductivity

\section{Introduction}

One of the greatest environmental concerns facing modern society is the use of fossil fuels for power generation

"Corresponding author.

How to cite this paper: de Aguiar, L.C.V., de Ramos Filho, F.G., Kawaguti, C.A. and de Souza Gomes, A. (2016) Synthesis of Poly (Ether Ether) Ketone Sulfonated Membrane with Tin Dioxide Particles. Journal of Materials Science and Chemical Engineering , 4, 49-60. http://dx.doi.org/10.4236/msce.2016.42006 
[1]-[3]. Studies of the synthesis and use of polymeric membranes for fuel cells (FC) in electrolytes have been extensively investigated by several researchers who seek to consolidate the use of polymer electrolyte membrane fuel cell (PEMFC) in environmental with average temperatures until $100^{\circ} \mathrm{C}$ [4]-[6].

Nafion ${ }^{\circledR}$, which is already established in the membrane market, is one of the products to be improved due to some drawbacks, such as its high cost and reduction in proton conductivity in an environment with low relative humidity [7]-[9]. Aromatic polymers, including poly (ether ether) ketone, arise as alternatives due to the possibility of increasing its conductivity by sulfonation reaction. Depending on the degree of sulfonation of the polymer, it may reduce its own dimensional and thermal stability [10].

Obtaining of hybrid membrane based on sulphonated poly (ether ether) ketone (SPEEK) has been described in literature by incorporating inorganic particles, such as silica [11], zirconia [12], titanium [13], among others [14]. However, the studies of the polymeric matrix with tin particles were only mentioned in some academic papers where the number of particles introduced in the matrix was around $20 \%-50 \%$ [15]. The main use of these particles is to maintain, or even improve, its properties, such as the thermal and dimensional stability lost during the sulfonation reaction.

Other studies on organic-inorganic hybrid proton conductive membranes obtained by the sol-gel process showed lower conduction of protons [16] [17]. The tin oxide particles are stable in a wide pH range, allowing modifications with inorganic surfactants and higher working range during the sol gel process. However, it should be considered that the pure particle is not proton conductive, which makes necessary the inclusion of a third component in the system to perform such function.

The phosphotungstic acid (HPW) has a strong interaction with the inorganic phase, which promotes agglomerates inside this phase [16]-[20]. The protons may exist in their isolated acids form or in solvated form creating water molecules protonated $\left(\mathrm{H}_{3} \mathrm{O}^{+}, \mathrm{H}_{5} \mathrm{O}_{2}^{+}\right)$[21]-[24].

In the present work two membranes groups were synthesized: one of the groups was used as control, containing SPEEK matrix with sulfonation degree (SD) of 55\% and tin oxide particles, and the other one with the same composition of the control group but containing HPW particles. In that way, it was possible to evaluate the use of HPW in the membranes doping and its effect on proton conductivity.

\section{Experimental}

\subsection{Instruments and Reagents}

Poly (ether ether) ketone (PEEK) from Victrex (molar mass $288 \mathrm{~g} \cdot \mathrm{mol}^{-1}$ ), sulfuric acid from Sigma Aldrich (ACS $98 \%$ of purity), $\mathrm{SnCl}_{4} \cdot 5 \mathrm{H}_{2} \mathrm{O}$ from Sigma Aldrich $\left(97.5 \%\right.$ of purity, molecular weight $350.58 \mathrm{~g} \cdot \mathrm{mol}^{-1}$ ), nmethyl-2-pyrrolidone (NMP) from Vetec $\left(99 \%\right.$ of purity, molecular weight $\left.99.13 \mathrm{~g} \cdot \mathrm{mol}^{-1}\right)$, and hydrated phosphotungstic acid $\left(\mathrm{H}_{3} \mathrm{PW}_{12} \mathrm{O}_{40} \times \mathrm{H}_{2} \mathrm{O}\right)$ from Fluka (AR). All of them were used as received.

\subsection{Synthesis of the Tin Particles}

The inorganic tin oxide $\left(\mathrm{SnO}_{2}\right)$ has been obtained by precipitation of $\mathrm{Sn}(\mathrm{IV})$ in the form of oxyhydroxide, with addition of ammonium hydroxide in aqueous solution of $\mathrm{SnCl}_{4} \cdot 5 \mathrm{H}_{2} \mathrm{O}\left(0.25 \mathrm{~mol} \cdot \mathrm{L}^{-1}\right)$. The system was then kept in reflux for 2 hours. Further, it was subjected to a static dialysis process for about a week, until the peptization of the dialyzed material was completed, thus obtaining a limpid and transparent suspension. After dialysis the peptized material was dried in an oven at $100^{\circ} \mathrm{C}$, yielding the oxide.

\subsection{Preparation of Hybrids Membranes}

The polymer was sulfonated as described in the literature, obtaining the DS of 55\% measured by titration [25]. First, for the preparation of membranes, the polymer was dissolved in NMP. The mass ratio of polymer/solvent mass was $20 \%$. Subsequently, the oxide was also dissolved in NMP. The polymer solutions and oxide (varying the concentration of $2 \%, 4 \%$ and $6 \% \mathrm{w} / \mathrm{w}$ ) already dispersed in the solvent were placed under stirring at $60^{\circ} \mathrm{C}$ until complete dissolution. After the HPW was dissolved ( $40 \%$ of the mass of tin oxide) it was also added to the solution. The following mixture was transferred to a preheated glass plate at $70^{\circ} \mathrm{C}$ for 24 hours, and then dried in a vacuum oven at $80^{\circ} \mathrm{C}$ for 72 hours, finally obtaining the membrane. Two groups of membranes were synthesized: one containing only tin particles and SPEEK matrix, named SS2, SS4 and SS6, according to the amount of oxide in the matrix, and the other that, besides the SPEEK matrix and tin particles contained HPW particles, named SH2, SH4 and SH6. 


\subsection{Energy-Dispersive Analysis of X-Ray Emission (EDX Analysis)}

As electrons of a given atom have different energies it is possible that the point of incidence of the beam determine the chemical elements in the sample, and thus identify which mineral is observed. Samples of the synthesized tin oxide were analyzed in the form of powder, free of water, and the analysis was performed under vacuum for 320 s. A Shimadzu EDX-720 analyzer was used.

\subsection{Dynamic Light Scattering}

The average diameter of the particles of tin oxide was determined by light scattering using the Malvern Zetasizer ZS equipment. The method used by the equipment is PCS (photon correlation spectrocopy) or dynamic light scattering, this method correlates the Brownian motion of the particles with its average diameter. The rating distribution of average particle diameter was made by dissolving $20 \mathrm{mg}$ of particles in $2 \mathrm{~mL}$ of $0.5 \mathrm{M}$ ammonium hydroxide. A $1 \mathrm{M} \mathrm{HCl}$ solution was used to perform measurements in neutral $\mathrm{pH}$.

\subsection{X-Ray Diffraction Patterns (XRD Analysis)}

The diffraction spectra were obtained by a Rigaku Miniflex diffractometer using CuK source, with a wavelength of $1.5418 \AA$. Operating conditions were $30 \mathrm{kV}$ voltage, $15 \mathrm{~mA}$ current, and diffraction angle scan range between 2 - 80 , with a speed of $0.05^{\circ} / \mathrm{min}$.

\subsection{Thermal Gravimetric (TGA) and Derivative Thermal Gravimetric (DTG) Analysis}

The thermal stability of the membranes was investigated using thermogravimetric analysis (TGA). The analysis was performed on a TA Instruments Q-50 V20 10 Build device 36. The variation of weight loss versus temperature of the material was measured under continuous flow of $\mathrm{N}_{2}$, using a temperature range from $30^{\circ} \mathrm{C}$ to $700^{\circ} \mathrm{C}$ and speed heating of $10^{\circ} \mathrm{C} / \mathrm{min}$.

\subsection{Differential Scanning Calorimetry (DSC) Analysis}

The glass transition temperature $\left(T_{g}\right)$ of the membranes was determined by differential scanning calorimetry (DSC). The first run was used to eliminate the thermal history of the polymer and initially the samples were heated from $30^{\circ} \mathrm{C}$ to $200^{\circ} \mathrm{C}$, at a rate of $10^{\circ} \mathrm{C} / \mathrm{min}$. under $\mathrm{N}_{2}$ atmosphere. The samples were then cooled to $30^{\circ} \mathrm{C}$ and a second heating was performed at a rate of $10^{\circ} \mathrm{C} / \mathrm{min}$. The $T_{g}$ was determined from the curves and data obtained in the second heating scan. It was used a DSC 204 F1 Phoenix Netzsch equipment.

\subsection{Water and Ethanol Solution Uptake Test}

Adsorption tests in water and in $20 \%$ ethanol solution $(\mathrm{v} / \mathrm{v})$ were performed at different temperatures $\left(30^{\circ} \mathrm{C}\right.$, $60^{\circ} \mathrm{C}$ and $80^{\circ} \mathrm{C}$ ) and 24 hours interval. The samples were cut into circles and immersed in the solution. The weight taken at the end of the time range was taken as wet weight $(W W)$. After the test the samples were dried in a vacuum oven. This weight was taken as dry weight $(D W)$. The total of water content or adsorbed ethanol (TS) was calculated using the Equation (1).

$$
T S=(W W-D W) \div D W \times 100
$$

\subsection{Pervaporation Test}

The pervaporation test consists in forcing a fluid to permeate through a membrane due to the application of vacuum in one of its sides, while the other is in contact with the solution to be permeated. For this test it was used a device assembled in the laboratory. The membrane was cut into a disk-shape and then placed in the cell, where the upper side is continuously fed with an aqueous solution of ethanol or deionized water, and the lower face was under constant vacuum permeation. The vapor which permeated the membrane was condensed and collected in traps immersed in liquid nitrogen. The test was performed with the flow of water and with an aqueous solution of $20 \%$ ethanol by mass in the temperatures of $30^{\circ} \mathrm{C}$ and $50^{\circ} \mathrm{C}$. The pervaporated materials were collected three times, on intervals of 1 hour between them. The amount of pervaporated material was calculated by the difference in mass of the dry trap, before running the test, and the trap with pervaporated material, calculat- 
ing the average of the three measures.

\subsection{Proton Conductivity}

Impedance spectroscopy was used in this work. Membranes were preconditioned in deionized water at $60^{\circ} \mathrm{C}$ for 1 hour and then placed between two graphite electrodes. The whole membrane/electrode set was placed in a stainless steel cell. The cell was then placed in a greenhouse and analyses were performed at the temperatures of $30^{\circ} \mathrm{C}, 60^{\circ} \mathrm{C}$ and $80^{\circ} \mathrm{C}$ using an Autolab PGSTAT-30 equipment. The proton conductivity was calculated using the Equation (2).

$$
\sigma=1 / R S
$$

where $\sigma=$ conductivity, $R=$ resistivity and $S=$ membrane area.

\section{Results and Discussion}

\subsection{Energy-Dispersive Analysis of X-Ray Emission (EDX Analysis)}

From the EDX analysis results it is possible to verify the synthesized components present in tin oxide and identify their compositions. The results (Table 1) showed that the synthesized oxide has $96.84 \%$ of tin oxide, a value considered suitable for applications as a load on the membranes.

\subsection{Dynamic Light Scattering}

From the synthesis performed polydisperse particles were obtained. Figure 1 shows the size distribution of the particles of the synthesized tin oxide. The values were in the micrometer range varying from $0.19-0.64 \mu \mathrm{m}$.

\subsection{X-Ray Diffraction Patterns}

The tin oxide has amorphous characteristics due to the amount of water absorbed, and depending on the heat

Table 1. Percentages of elements present in $\mathrm{SnO}_{2}$.

\begin{tabular}{ccc}
\hline Sample & Element & Percentage (w/w) \\
\hline & $\mathrm{SnO}_{2}$ & 96.84 \\
$\mathrm{SiO}_{2}$ & 1.36 \\
$\mathrm{CaO}$ & 1.35 \\
\multirow{2}{*}{ Tin dioxide } & $\mathrm{SO}_{3}$ & 0.19 \\
& $\mathrm{Tm}_{2} \mathrm{O}_{3}$ & 0.15 \\
& $\mathrm{CuO}$ & 0.042 \\
& $\mathrm{ZnO}$ & 0.038 \\
\hline
\end{tabular}

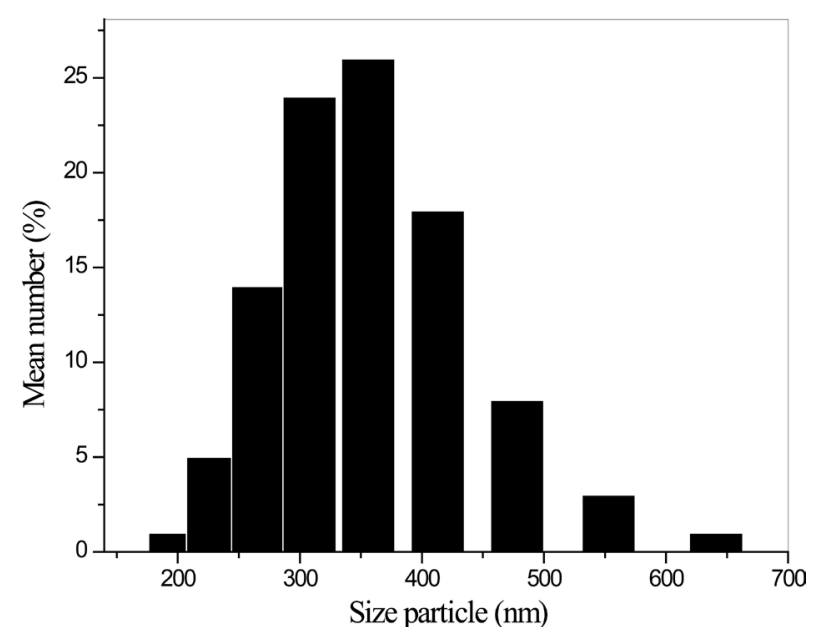

Figure 1. Particle size distribution. 
treatment performed, some peaks can be narrowed forming nanocrystals [15] [26]. Comparing the spectra obtained for pure tin oxide with other studies, the formed oxide corresponds to form crystallographic rutile. By the analysis of Figure 2(a) shows that the introduction of tin oxide increased the crystallinity of the membranes, verified by the narrowing of the peak in the region of $2 \theta=20$ as the amount of the oxide introduced into the membrane increased. Such behavior can be associated with the good dispersion of the oxide particles in the polymer matrix, generating points for nucleation.

Membranes that possess HPW, in addition to the tin oxide particles, exhibit behavior similar to that presented hybrid membranes with pure oxide particle. From Figure 2(b), it was verified that the introduction of HPW somehow interacted with the polymer, since the displacement of the amorphous halo with center $2 \theta=20$ at larger angles. This behavior can be explained, for the insertion of HPW may have hindered the packing of polymer chains and nucleation of smaller particles of tin oxide.

\subsection{Thermal Gravimetric (TGA) and Derivative Thermal Gravimetric (DTG) Analysis}

The thermal degradation of SPEEK occurs after three major events. The first phase occurs at approximately $100^{\circ} \mathrm{C}$ and is related to the loss of free water. In other words, water which is not bound in the polymer structure. In the second step, around $200^{\circ} \mathrm{C}$, there is a loss of sulfonic acid groups, which do not always occur at the same temperature due to uneven distribution of it in polymer chain, the loss of residual solvent (in some cases, after the drying process, it can remain approximately $5 \%$ of the solvent), and also the loss of water attached in the polymer chains. These water molecules can be attached through either chemical bonds or interactions. The third stage, which takes place around $450^{\circ} \mathrm{C}$, is related to the degradation of the polymer chain [27].

The values of mass loss and maximum degradation temperature displayed for each phase were taken from the TGA and DTG analysis presented in Figure 3(a) and Figure 3(b). In general, by adding tin oxide in the membranes, they showed a reduction in mass loss, even compared to the pure polymer.

In the values shown in Table 2 it can be seen that, regardless of the studied group of membranes, all had smaller amount of mass lost in the first stage, showing that the hybrid membranes have better conditions to maintain the polymer hydrates domains. However, the amount of particles on the membrane had little influence on the variation of weight loss in this region.

In the first event of the second region, the greater weight loss compared to pure polymer may be a consequence of the increased amount of solvent, which has been used to solubilize the polymer and it was also used to disperse the tin oxide and HPW particles. Regarding the maximum temperature of degradation, by increasing the amount of tin oxide it was observed a slight decrease of the maximum degradation temperature. Meanwhile, in the membranes of the SH group, there is an increase in the maximum degradation temperature with the increase in the percentage of HPW in SPEEK matrix. That is, an improvement in thermal stability, which means that the

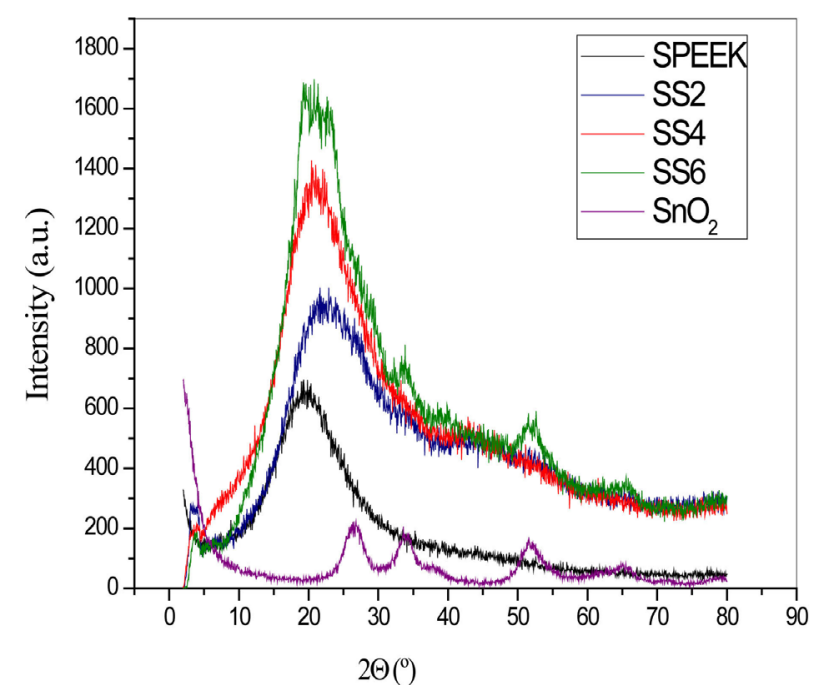

(a)

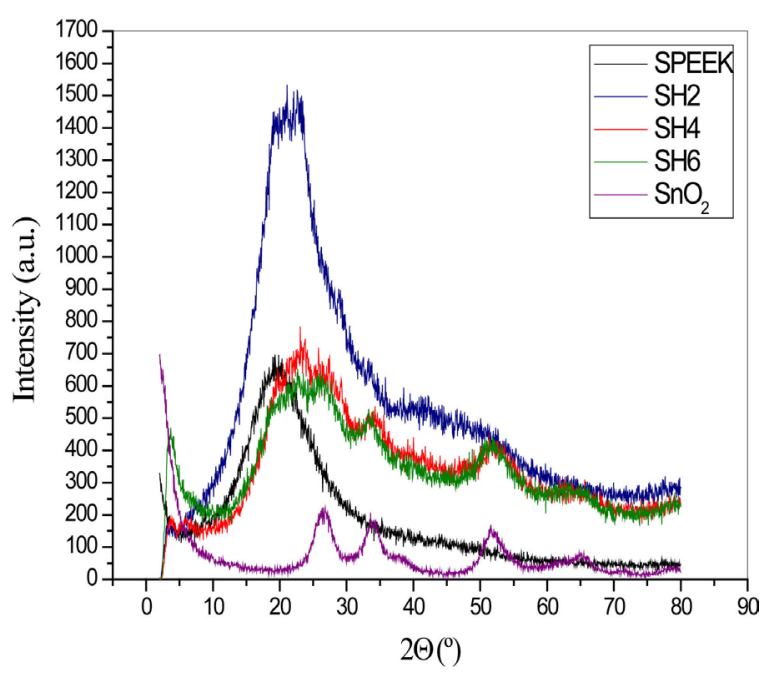

(b)

Figure 2. XRD patterns of the membranes containing $\mathrm{SnO}_{2}$ particles (a) and $\mathrm{SnO}_{2}$ and $\mathrm{HPW}$ particles (b). 


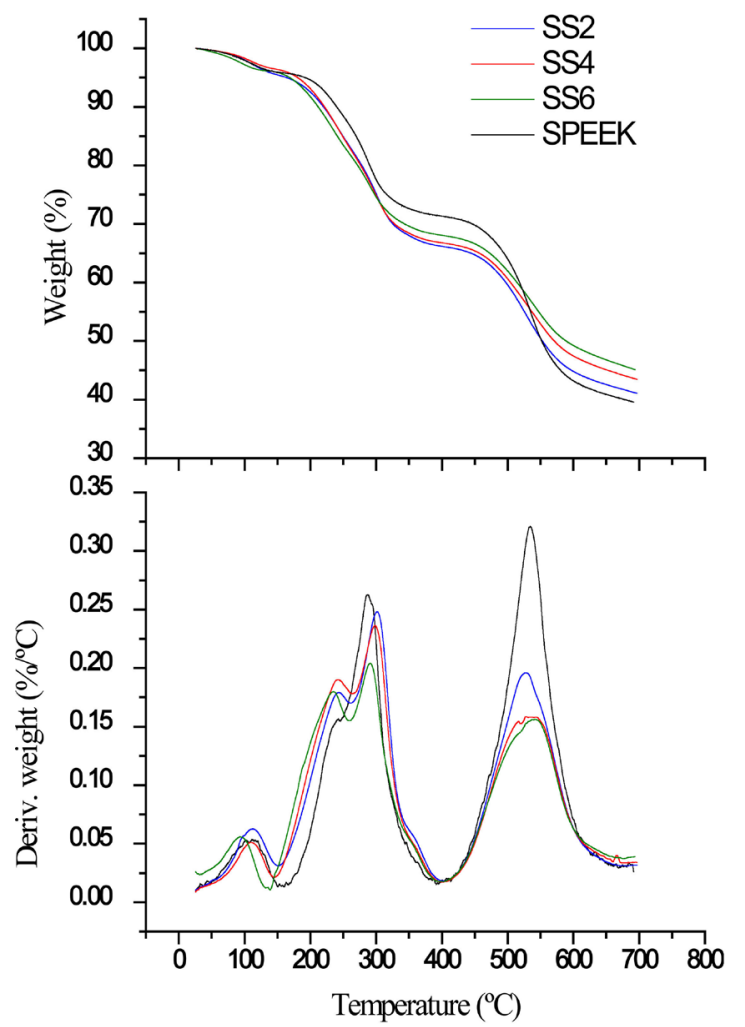

(a)

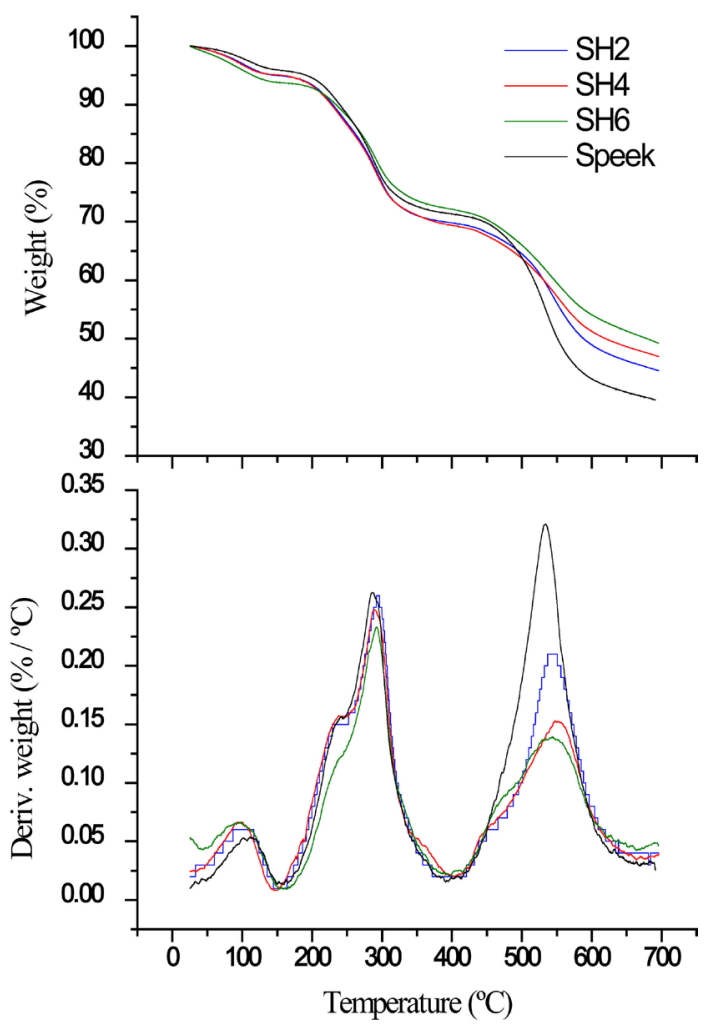

(b)

Figure 3. TGA analyses of the membranes containing $\mathrm{SnO}_{2}$ particles (a) and $\mathrm{SnO}_{2}$ and $\mathrm{HPW}$ particles (b).

Table 2. Values taken from TGA and DTG analysis of membranes.

\begin{tabular}{|c|c|c|c|c|c|c|c|}
\hline \multirow[b]{2}{*}{ Samples } & \multicolumn{3}{|c|}{ Weight Loss (\%) } & \multirow{2}{*}{$\begin{array}{c}\text { Total Weight Loss (\%) } \\
-\end{array}$} & \multicolumn{3}{|c|}{ Maximum Degradation Temperature $\left({ }^{\circ} \mathrm{C}\right)$} \\
\hline & $1^{\text {st }}$ stage & $2^{\text {nd }}$ stage & $3^{\text {rd }}$ stage & & $1^{\text {st }}$ stage & $2^{\text {nd }}$ stage & $3^{\text {rd }}$ stage \\
\hline SPEEK & 4.70 & 26.97 & 32.84 & 64.71 & 106.41 & 289.36 & 538.15 \\
\hline SS2 & 4.55 & 29.38 & 24.96 & 58.90 & 113.50 & 301.37 & 527.80 \\
\hline SS4 & 3.53 & 29.66 & 23.33 & 56.54 & 108.97 & 297.99 & 527.01 \\
\hline SS6 & 3.93 & 27.98 & 23.00 & 54.92 & 95.35 & 293.72 & 544.50 \\
\hline SH2 & 4.14 & 29.86 & 21.80 & 55.81 & 105.94 & 295.01 & 544.35 \\
\hline SH4 & 3.96 & 30.55 & 20.79 & 55.26 & 105.98 & 295.00 & 547.37 \\
\hline SH6 & 4.23 & 28.57 & 21.63 & 54.57 & 113.05 & 298.07 & 543.84 \\
\hline
\end{tabular}

conductor groups remain on the membrane for a longer time when it is exposed to a higher temperature.

In the third phase, it was observed a mass loss reduction in both groups of hybrid membranes due to the increase of inorganic portion at the polymer matrix. There was an improvement in the thermal stability of the synthesized membranes since in the SS group to increase the oxide amount in up to 6\% (SS6) showed a slight increase in the maximum degradation temperature relative to SPEEK membrane. Already in SH group the maximum temperature degradation was achieved with the SH4 membrane.

\subsection{Differential Scanning Calorimetry (DSC) Analysis}

The DSC analysis results, shown in Figure 4, investigated the $T_{g}$ of the membranes. From Table 3 it was found that the incorporation of both particles, $\mathrm{HPW}$ and $\mathrm{SnO}_{2}$, decreased the $T_{g}$ when compared to the pure polymer, thus providing greater mobility of the amorphous part of the polymer chain. The lower $T_{g}$ of SH membranes group compared to SS group is related to the state of hydration of the membranes because, besides the change in 


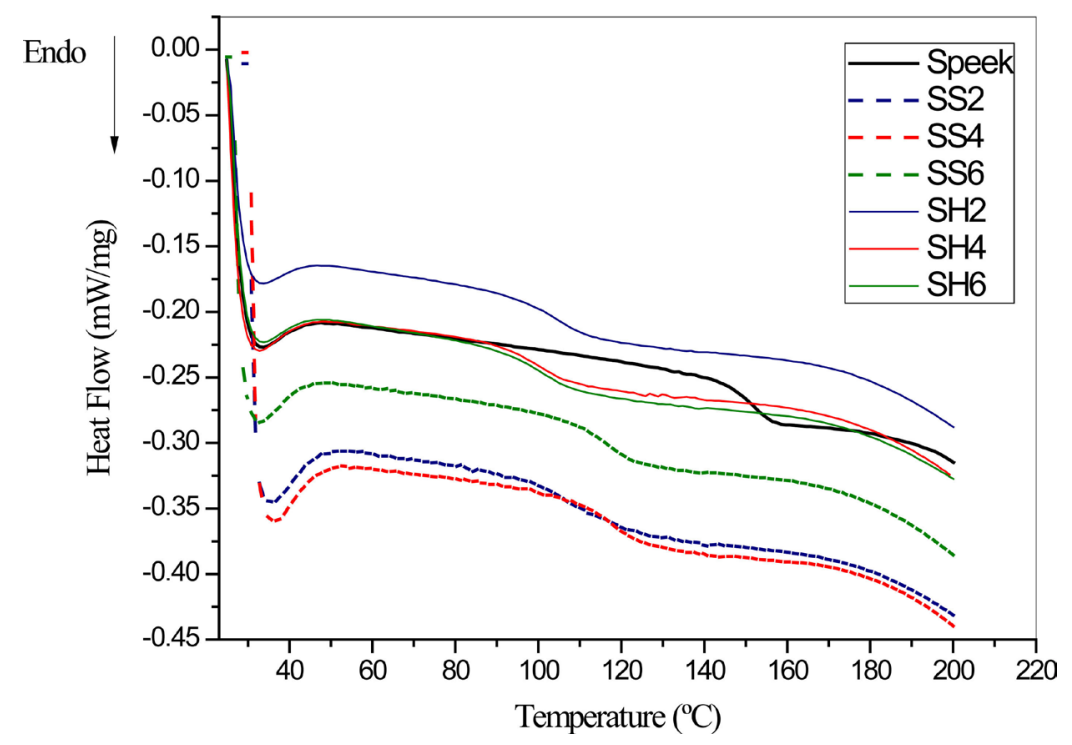

Figure 4. Influence of the particles in the membranes $T_{g}$ measured by DSC.

Table 3. $T_{g}$ values taken from the middle of the inflection point obtained from the second run in the DSC analyses.

\begin{tabular}{cc}
\hline Samples & $\boldsymbol{T}_{\boldsymbol{g}}$ values $\left({ }^{\circ} \mathbf{C}\right)$ \\
\hline SPEEK & 152.3 \\
SS2 & 106.1 \\
SS4 & 108.4 \\
SS6 & 113.4 \\
SH2 & 107.2 \\
SH4 & 102.1 \\
SH6 & 100.4 \\
\hline
\end{tabular}

the sulfonic group of the polymer, HPW particles provide greater hydrophilic character and increase the free volume present in these membranes [28].

\subsection{Water and Ethanol Solution Uptake Test}

Figure 5 shows the result of swelling in water. It can be seen that all hybrid membranes maintains better dimensional stability at temperatures up to $80^{\circ} \mathrm{C}$, compared to pure polymer since a lower percentage of swelling of these membranes. It was also noted increased swelling at $80^{\circ} \mathrm{C}$ for all membranes synthesized, this is due to the intense movement of the chains caused by temperature. With respect to SS membranes group to introduce up to $4 \%$ of $\mathrm{SnO}_{2}$ particles approximately $5 \%$ of reduced swelling compared to pure polymer when measured at $30^{\circ} \mathrm{C}$, and reduced the swelling by over $30 \%$ when measured at $80^{\circ} \mathrm{C}$. The HPW is a hygroscopic material [28]-[30], and therefore the greatest degree of swelling of this membrane group than in the SS membranes group was expected. However, even when introducing the larger amount of HPW tested in this work the SH membranes showed less swelling than pure SPEEK membrane, especially when tested at $80^{\circ} \mathrm{C}$. This result shows that the particles, despite the increased mobility of the chains, promoted a degree of crosslinking to prevent excessive swelling.

Figure 6 shows the swelling results in ethanol solution. This test followed the same trajectory in the swelling test in water, but since the beginning of the test, at $30^{\circ} \mathrm{C}$, the hybrid membranes have been less swelling compared to pure polymer.

\subsection{Selective Permeability of Membranes}

Among the search by different sources hydrogen, alcohols such as methanol and ethanol have been widely considered for use in fuel cells. The Nafion presents problems known as methanol crossover, reducing the performance 


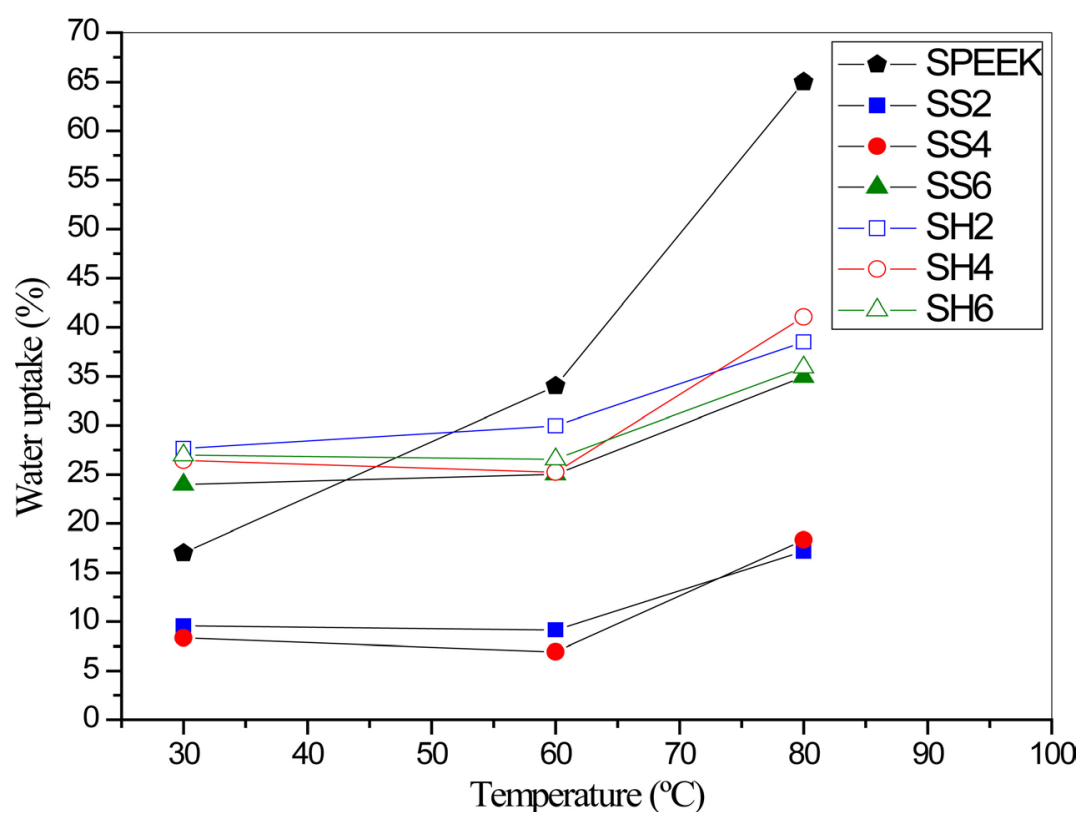

Figure 5. Results of the water uptake tests.

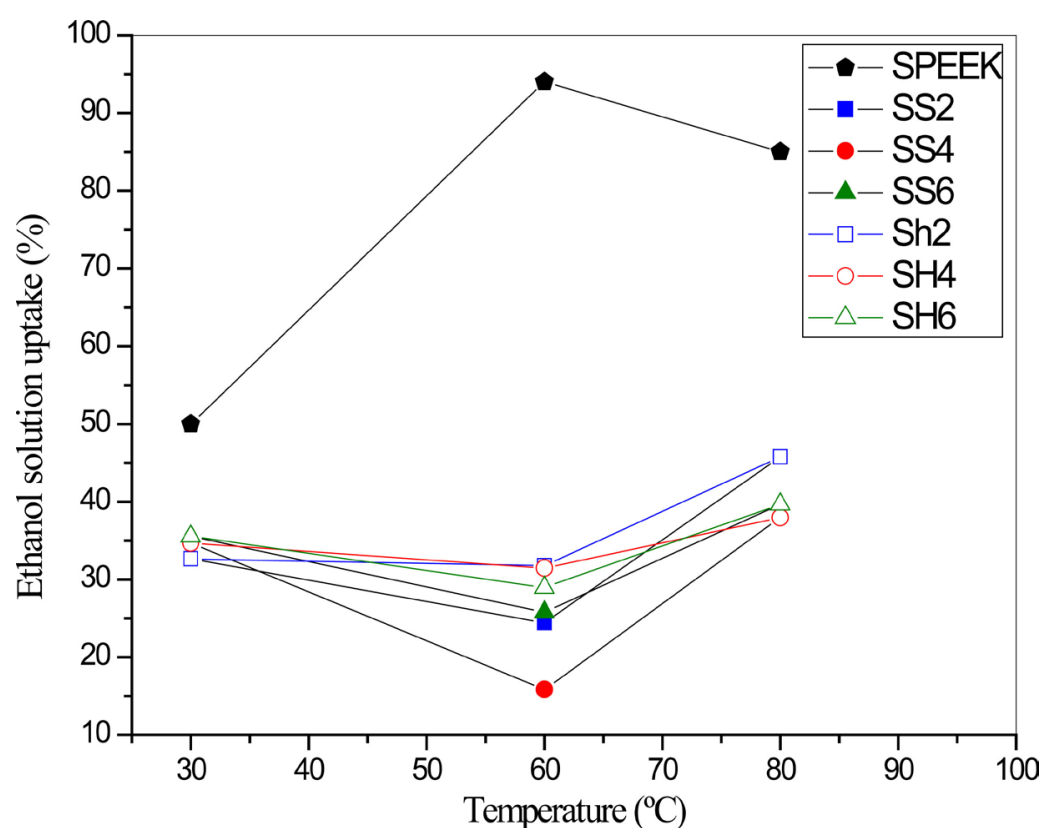

Figure 6. Results of ethanol solution uptake tests.

of the cell [29] [31]. Therefore, to place the membranes in the current scenario, in order to be able to use alcohol as fuel, the developed membranes were also tested for permeability alcohol and the obtained values were shown in Table 4.

In Figure 7(a) and Figure 7(b) it can be seen that both groups of hybrid membranes have a better ethanol barrier property than pure SPEEK membrane. According to Xiang et al. (2011) this behavior can be explained by the amount of sulfonic acid groups in the polymer chains, since the passage of ethanol through the membrane preferentially occurs by hydrophilic domains. The ability of the hybrid membranes to be less permeable to ethanol solution is associated with the change in the structure of the membranes, since the insertion of the oxide and acid particles reduces the available cross channels that the alcohol molecules pass. That is, they form a physical barrier which prevents the passage path of alcohol molecules [22]. 
Table 4. Values of the permeation test.

\begin{tabular}{|c|c|c|c|c|}
\hline \multicolumn{5}{|c|}{ Permeate Flow $\left(\mathrm{Kg} / \mathrm{m}^{2} \mathrm{~h}\right)$} \\
\hline \multirow[b]{2}{*}{ Samples } & \multicolumn{2}{|c|}{ Pervaporation at $30^{\circ} \mathrm{C}$} & \multicolumn{2}{|c|}{ Pervaporation at $50^{\circ} \mathrm{C}$} \\
\hline & Water & Ethanol Solution & Water & Ethanol Solution \\
\hline SPEEK & 0.14 & 1.00 & 0.20 & 2.5 \\
\hline $\mathrm{SS} 2$ & 0.17 & 0.21 & 0.16 & 0.15 \\
\hline SS4 & 0.19 & 0.15 & 0.21 & 0.55 \\
\hline SS6 & 0.20 & 0.20 & 0.23 & 0.79 \\
\hline SH2 & 0.09 & 0.080 & 0.084 & 0.20 \\
\hline SH4 & 0.30 & 0.35 & 0.24 & 0.35 \\
\hline SH6 & 0.086 & 0.075 & 0.20 & 0.25 \\
\hline
\end{tabular}

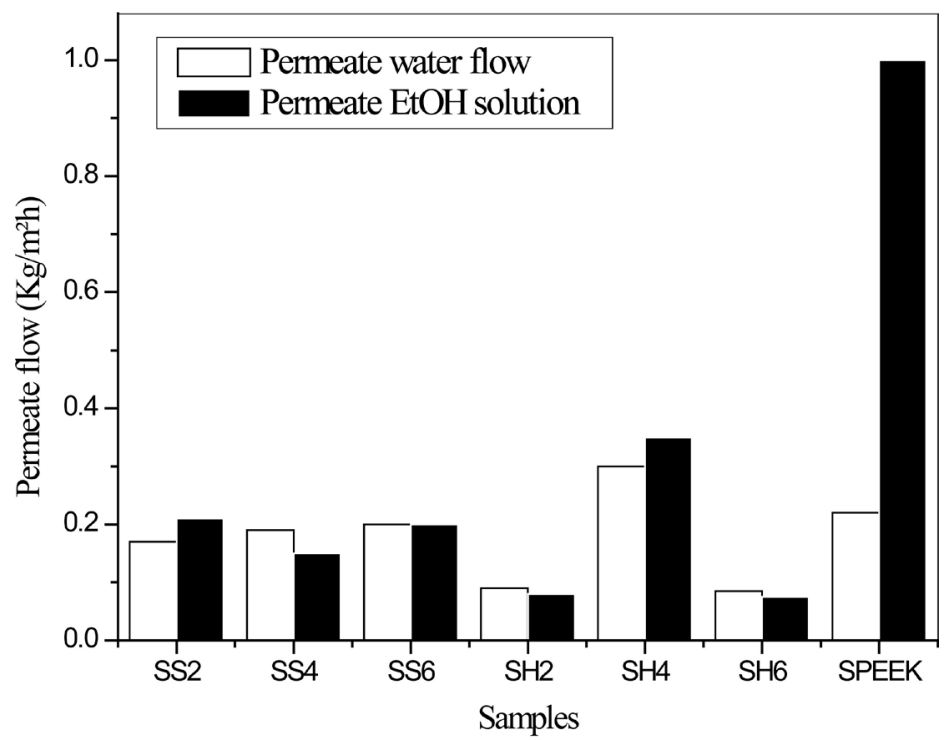

(a)

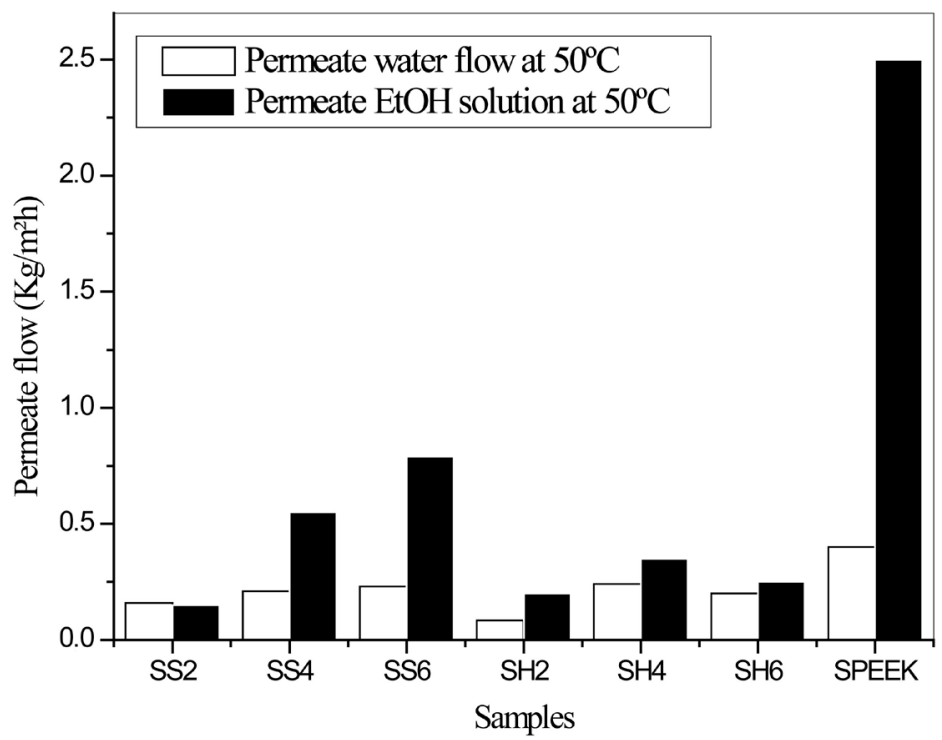

(b)

Figure 7. Permeability of the membranes in water and in ethanol solution at $30^{\circ} \mathrm{C}$ (a) and $50^{\circ} \mathrm{C} \mathrm{(b)}$. 
Table 5. Proton conductivity results of synthetized membranes.

\begin{tabular}{ccccccccc}
\hline & \multicolumn{7}{c}{ Conductivity $(\mathrm{mS} / \mathrm{cm})$} \\
\hline Samples without HPW & $30^{\circ} \mathrm{C}$ & $60^{\circ} \mathrm{C}$ & $80^{\circ} \mathrm{C}$ & Samples with HPW & $30^{\circ} \mathrm{C}$ & $60^{\circ} \mathrm{C}$ & $80^{\circ} \mathrm{C}$ \\
\hline SPEEK & 10.20 & 14.00 & 28.60 & - & - & - & - \\
SS2 & 16.42 & 30.56 & 45.37 & SH2 & 7.70 & 16.79 & 28.98 \\
SS4 & 25.80 & 49.69 & 67.80 & SH4 & 14.70 & 23.21 & 35.11 \\
SS6 & 7.77 & 14.54 & 21.96 & SH6 & 14.95 & 34.66 & 50.44 \\
\hline
\end{tabular}

\subsection{Proton Conductivity}

Table 5 shows the proton conductivity values obtained for the two groups of membranes. It is possible to verify a different behavior for each group. In the group composed only by tin oxide particles (membranes SS2, SS4 and SS6), there was an increase in the proton conductivity of the membranes. But when it was used the proportion greater than $4 \%$ of $\mathrm{SnO}_{2}$ proton conductivity values dropped again. In this group the maximum conductivity reached was $67.8 \mathrm{mS} / \mathrm{cm}$ at $80^{\circ} \mathrm{C}$. In the second group, membranes with tin oxide and HPW, it was found that the proton conductivity increased due to the addition of HPW. However, there were no major changes in the proton conductivity values comparing composite membranes with the SPEEK/SnO $\mathrm{S}_{2}$ ones. So, larger amounts of HPW are needed to achieve higher conductivity values seen, showing that when HPW was introduced it preferably interacted with the polymer chains, giving them a more amorphous character.

\section{Conclusion}

The developed membranes series showed good capacity of absorption of water in temperatures up to $80^{\circ} \mathrm{C}$ when compared to SPEEK. The introduction of tin oxide and HPW increased the mobility of the polymer chains. However, they caused no major changes in the thermal stability, with lower mass loss values than SPEEK ones, as verified at the TGA analyses. The highest value of conductivity was $67.80 \mathrm{mS} / \mathrm{cm}$ for the SS4 membrane. An increase was observed in proton conductivity in the SH group membranes due to the addition of HPW. This suggests that the concentration of HPW particles used in this work was not the best to achieve better proton conductivity results in the SH group membranes and the amount of HPW should be increased.

\section{Acknowledgements}

The authors thank CNPq for the financial support for this research.

\section{References}

[1] Pei, P.C. and Chen, H.C. (2014) Main Factors Affecting the Lifetime of Proton Exchange Membrane Fuel Cells in Vehicle Applications: A Review. Applied Energy, 125, 60-75. http://dx.doi.org/10.1016/j.apenergy.2014.03.048

[2] Ho, J.C., Saw, E.-C., Lu, L.Y.Y. and Liu, J.S. (2014) Technological Barriers and Research Trends in Fuel Cell Technologies: A Citation Networks Analysis. Technological Forecasting and Social Change, 82, 66-79. http://dx.doi.org/10.1016/j.techfore.2013.06.004

[3] Wang, Y., Chen, K.S., Misheler, J., Cho, S.C. and Adroher, X.C. (2011) A Review of Polymer Electrolyte Membrane Fuel Cells: Technology, Applications and Needs on Fundamental Research. Applied Energy, 88, 981-1007. http://dx.doi.org/10.1016/j.apenergy.2010.09.030

[4] Fiori, C., Dell’Era, A., Zuccari, F., Santiangeli, A., D’Orazio, A. and Orecchini, F. (2015) Critical Review of Fuel Cell's Membranes and Identification of Alternative Types for Automotive Applications. International Journal of Hydrogen Energy, 40, 11949-11959. http://dx.doi.org/10.1016/j.ijhydene.2015.03.105

[5] Sharafi, O.Z. and Orhan, M.F. (2014) An Overview of Fuel Cell Technology: Fundamentals and Applications. Renewable and Sustainable Energy Reviews, 32, 810-853. http://dx.doi.org/10.1016/j.rser.2014.01.012

[6] Bakangura, E., Wu, L., Ge, L., Yang, Z. and Xu, T. (2016) Mixed Matrix Proton Exchange Membranes for Fuel Cells: State of the Art and Perspectives. Progress in Polymer Science, in Press. http://dx.doi.org/10.1016/j.progpolymsci.2015.11.004

[7] Prapainainar, P., Theampetch, A., Kongkachuichay, P., Laosiripojana, N., Holmes, S.M. and Prapainainar, C. (2015) Effect of Solution Casting Temperature on Properties of Nafion Composite Membrane with Surface Modified Mordenite for Direct Methanol Fuel Cell. Surface and Coaching Technology, 271, 63-73. http://dx.doi.org/10.1016/j.surfcoat.2015.01.021 
[8] Devrim, Y. and Albostan, A. (2015) Enhancement of PEM Fuel Cell Performance at Higher Temperatures and Lower Humidities by High Performance Membrane Electrode Assembly Based on Nafion/Zeolite Membrane. International Journal of Hydrogen Energy, 40, 15328-15335.

[9] Zheng, J.F., He, Q.Y., Liu, C.L., Yuan, T., Zhang, S.B. and Yang, H. (2015) Nafion-Microporous Organic Polymer Networks Composite Membranes. Journal of Membrane Science, 476, 571-579. http://dx.doi.org/10.1016/j.memsci.2014.10.057

[10] Handayani, S., Dewi, E.L., Hardy, J., Christiani, L. and Kurniawan (2012) Influence of Composite Electrolyte Membrane for Proton Exchange Membrane Fuel Cells. Procedia Chemistry, 4, 123-130. http://dx.doi.org/10.1016/j.proche.2012.06.018

[11] Du, L., Yan, X., He, G., Wu, X., Hu, Z. and Wang, Y. (2012) SPEEK Proton Exchange Membranes Modified with Silica Sulfuric Acid Nanoparticle. International Journal of Hydrogen Energy, 37, 11853-11861. http://dx.doi.org/10.1016/j.ijhydene.2012.05.024

[12] Pandey, J., Seepana, M.M. and Shukla, A. (2015) Zirconium Phosphate Based Proton Conducting Membrane for DMFC Application. International Journal of Hydrogen Energy, 40, 9410-9421. http://dx.doi.org/10.1016/j.ijhydene.2015.05.117

[13] Di Vona, M.L., Sgreccia, E., Donnadio, A., Casciola, M., Chailan, J.F., Auer, G. and Knauth, P. (2011) Composite Polymer Electrolytes of Sulfonated Poly-Ether-Ether Ketone (SPEEK) with Organically Functionalized $\mathrm{TiO}_{2}$. Journal of Membrane Science, 369, 536-544. http://dx.doi.org/10.1016/j.memsci.2010.12.044

[14] Kim, D.J., Jo, M.J. and Nam, S.Y. (2015) A Review of Polymer-Nanocomposite Electrolyte Membranes for Fuel Cell Application. Journal of Industrial and Engineering Chemistry, 21, 36-52. http://dx.doi.org/10.1016/j.jiec.2014.04.030

[15] Mecheri, B., D’Epifanio, A., Taversa, E. and Liccocia, S. (2008) Sulfonated Polyether Ether Ketone and Hydrated Tin Oxide Proton Conducting Composites for Direct Methanol Fuel Cell Applications. Journal of Power Sources, 178, 554-560. http://dx.doi.org/10.1016/j.jpowsour.2007.09.072

[16] Xiang, Y., Yang, M., Zhang, J., Lan, F. and Lu, S. (2011) Phosphotungstic Acid (HPW) Molecules Anchored in the Bulk of Nafion as Methanol-Blocking Membrane for Direct Methanol Fuel Cells. Journal of Membrane Science, 368, 241-245.

[17] Cui, Z, Xing, W., Liu, C., Liao, J. and Zhang, H. (2009) Chitosan/Heteropolyacid Composite Membranes for Direct Methanol Fuel Cell. Journal of Power Sources, 188, 24-29. http://dx.doi.org/10.1016/j.jpowsour.2008.11.108

[18] Aguiar, L.C.V., Ramos Filho, F.G. and Gomes, A.S. (2014) Membranes of PVA and Sílica for Application in Direct Alcohol Fuel Cell. Polímeros ciência e tecnologia, 24, 689-693. http://dx.doi.org/10.1590/0104-1428.1553

[19] Gomes, A.S. and Dutra Filho, J.C. (2012) Hybrid Membranes of PVA for Direct Ethanol Fuel Cell. International Journal of Hydrogen Energy, 37, 6246-6252. http://dx.doi.org/10.1016/j.ijhydene.2011.08.002

[20] Wu, H., Shen, X., Cao, Y., Li, Z. and Jiang, Z. (2014) Composite Proton Conductive Membranes Composed of Sulfonated Poly(Ether Ether Ketone) and Phosphotungstic Acid-Load Imidazole Microcapsules as Acid Reservoirs. Journal of Membrane Science, 451, 74-84. http://dx.doi.org/10.1016/j.memsci.2013.09.058

[21] Wang, H., Zhuang, X., Li, X., Wang, W., Wang, Y. and Cheng, B. (2015) Solution Blown Sulfonated Poly(Ether Sulfone)/Poly(Ether Sulfone) Nanofiber-Nafion Composite Membranes for Proton Exchange Membrane Fuel Cell. Journal of Applied Polymer Science, 132, 42572-42579.

[22] Tian, N., Wu, X., Yang, B., Wu, Q., Cao, F., Yan, W. and Yaroslavtsev, A.B. (2015) Proton-Conductive Membranes Based on Vanadium Substituted Heteropoly Acids with Keggin Structure and Polymers. Journal of Applied Polymer Science, 132, 42204-42211. http://dx.doi.org/10.1002/app.42204

[23] Lin, C., Haolin, T. and Mu, P. (2012) Periodic Nafion-Silica-Heteropolyacids Electrolyte for PEM Fuel Cell Operated near $200^{\circ} \mathrm{C}$. International Journal of Hydrogen Energy, 37, 4694-4698. http://dx.doi.org/10.1016/j.ijhydene.2011.04.116

[24] Zhang, J. and Gao, L. (2004) Synthesis and Characterization of Nanocrystalline Tin Oxide by Sol Gel Method. Journal of Solid State Chemistry, 177, 1425-1430. http://dx.doi.org/10.1016/j.jssc.2003.11.024

[25] Huang, R.Y.M., Pingahy, S., Burns, C.M. and Feng, X. (2001) Sulfonation of Poly(Ether Ether Ketone) (PEEK): Kinetic Study and Characterization. Journal of Applied Polymer Science, 82, 2651-2660. http://dx.doi.org/10.1002/app.2118

[26] Knauth, P., Hou, H., Bloch, E., Sgreccia, E. and Di Vona, M.L. (2011) Thermogravimetric Analysis of SPEEK Membranes: Thermal Stability, Degree of Sulfonation and Cross-Linking Reaction. Journal of Analytical Applied Pyrolysis, 92, 361-365. http://dx.doi.org/10.1016/j.jaap.2011.07.012

[27] Amirinejad, M., Madaeni, S.S., Navarra, M.A., Rafiee, E. and Scrosati, B. (2011) Preparation and Characterization of Phosphotungstic Acid-Derived Salt/Nafion Nanocomposite Membranes for Proton Exchange Membrane Fuel Cells. Journal of Power Sources, 196, 988-998. http://dx.doi.org/10.1016/j.jpowsour.2010.08.062 
[28] Ren, S., Xu, M., Yang, Y., Ma, S. and Hao, C. (2014) Effects of Microstructural Functional Polyaniline Layers on SPEEK/HPW Proton Exchange Membranes. Journal of Applied Polymer Science, 132, 42204-42211. http://dx.doi.org/10.1002/app.41033

[29] Xu, L., Xu, J., Liu, M., Han, H., Ni, H., Ma, L. and Wang, Z. (2015) Fabrication of Sulfonated Poly(Aryl Ether Ketone Sulfone) Membranes Blended with Phosphotungstic Acid and Microporous Poly(Vinylidene Fluoride) as a Depository for Direct-Methanol Fuel Cells. International Journal of Hydrogen Energy, 40, 7182-7191.

[30] Lu, J.L., Fang, Q.H., Li, S.L. and Jiang, S.P. (2013) A Novel Phosphotungstic Acid Impregnated Meso-Nafion Multilayer Membrane for Proton Exchange Membrane Fuel Cells. Journal of Membrane Science, 42, 101-107. http://dx.doi.org/10.1016/j.memsci.2012.09.041

[31] Zeng, J., Shen, P.K., Lu, S., Xiang, Y., Li, L., De Marco, R. and Jiang, S.P. (2012) Correlation between Proton Conductivity, Thermal Stability and Structural Symmetries in Novel HPW-Meso-Silica Nanocomposite Membranes and Their Performance in Direct Methanol Fuel Cells. Journal of Membrane Science, 397-398, 92-101. http://dx.doi.org/10.1016/j.memsci.2012.01.018 